\title{
THE YELLOW IMMACULATE LILY IN SASKATCHEWAN AND ADJACENT MANITOBA, AND ITS PERSISTENCE IN NATIVE LILY PATCHES
}

DORIS SILCOX, Box 549, Carlyle, Saskatchewan, S0C 0R0, and VERNON L. HARMS, The W.P. Fraser Herbarium and Biology Department, University of Saskatchewan, Saskatoon, Saskatchewan. S7N 0W0

The beautiful native "Yellow Immaculate Lily," characterized by unspotted, lemon-yellow perianth parts, is an apparently very rare, naturally occurring colour form of the common Western Red Wood Lily (or "Prairie Lily"), Saskatchewan's official floral emblem. This yellowflowered lily form was first discovered and collected by E.H. Moss (no. 2213, $\mathrm{GH})$ from Jenkins Lake, northwest of Athabasca, Alberta, at 68-24-W4 (54 $56^{\prime} \mathrm{N}$, $113^{\circ} 36^{\prime} \mathrm{W}$ ) and formally described and named in 1934 by H.M. Raup as Lilium philadelphicum L. var. andinum (Nutt.) Ker. forma immaculatum Raup. ${ }^{3}$

In the Flora of Canada, H.J. Scoggan listed it only from the type locality of Jenkins Lake, Alberta. ${ }^{4}$ In his Flora of the Prairie Provinces, Bernard Boivin indicated its certain presence only in Alberta but parenthetically included both Saskatchewan and Manitoba, his method of indicating either unsubstantiated reports or his own expectation that the taxon might possibly occur in these provinces although not yet verified. ${ }^{1}$

The first published report of the Yellow Immaculate Lily in Saskatchewan was by Brian Irving, based on his discovery in July 1982 of some yellow lilies on his farm at two local sites nearly a mile apart, about 5 and $5.5 \mathrm{mi}$. southwest of Kelvington, in SW and NW 23-36-12-W2, respectively. ${ }^{2}$ These were growing among numerous normal red-flowered lilies on slightly saline native meadows and consisted of one and two fully yellow and unspotted lilies respectively at the two sites, plus three plants of inter- mediate colour form at the latter site. They were reportedly visited on 15 July 1982 and verified as the Yellow Immaculate form of the Western Red Wood Lily by J.R. Jowsey, a coauthor of the book Wildflowers Across the Prairies. ${ }^{5}$

But earlier, on 28 June 1978, Doris Silcox had discovered a yellow-flowered lily in a patch of red-flowered lilies in a roadside ditch on the $s$ side of former Highway 13, about 4 mi. east-southeast of Carlyle at the ne corner of NW 34-7-2W2. The site was visited in late June 1979 by Fenton Vance, another coauthor of Wildflowers Across the Prairies ${ }^{5}$, who verified and photographed the three yellow lilies then present.

Subsequently, in 1983 two yellow lilies were also found by Doris Silcox $2 \mathrm{mi}$. north of the originally discovered colony, along a roadside ditch $2.5 \mathrm{mi}$. east of Carlyle in 15-8-2-W2. Later, when road construction threatened the imminent destruction of this site, the two yellow lily plants were transplanted to her yard about 4 mi. east-southeast of Carlyle, at the sw corner of SE 3-8-2-W2.

All of the yellow-flowered lilies observed by Doris Silcox at the Carlyle area sites were the pure Yellow Immaculate Lily form, with pale yellow unspotted perianth parts, growing among typical red-flowered lilies; no apparently intermediate colour forms were noted.

After the publication of his finding of yellow lilies in the Kelvington area, Brian Irving received correspondence from 
various other naturalists who had also observed and sometimes photographed such yellow lilies elsewhere in Saskatchewan and adjacent western Manitoba (pers. comm. B. Irving to V.L. Harms, Dec. 1988). Each of these respondents was contacted recently by V.L. Harms in an attempt to validate their finds and possibly determine the subsequent history of each yellow lily colony. Based on the information and usually colour photographs kindly provided by these respondents, the following additional locality records for the Yellow Immaculate Lily can now be reported.

Dr. A.J. Porter, of Honeywood Nursery, Parkside, related that in the late 1950 s or early 1960 s (date uncertain), he had found a yellow native lily about a mile south of the Emerald Lake Regional Park entrance, about $10 \mathrm{mi}$. south-southeast of Shell Lake, in W 27-48-7-W3. By description and his identification it was the pure Yellow Immaculate Lily form. Later Dr. Porter also found a yellow native lily on his own property about $4 \mathrm{mi}$. south-southeast of Parkside, in SE 6-48-4W3. Although definitely yellow, this lily had pinkish-mauve spots on the perianth segments, thus representing an intermediate colour form. Both of the above plants had been transplanted by him to his nursery, where the first plant survived and bloomed for only a couple of years and the second did not survive the transplantation. According to Dr. Porter, this is a difficult species to maintain in cultivation. There are no voucher specimens or colour photographs to further document these sight records (pers. comm. A.J. Porter to V.L. Harms, 25 Feb. 1989).

On 5 July 1979, David Meyer, then an archaeologist with the Saskatchewan Research Council, discovered and photographed some yellow lilies among an abundance of typical Western Red Wood Lilies on a hillside on the s side of Gordon Bay of Gordon Lake, between km 30 and 31 of the Pinehouse-Key Lake Road, about $3.5 \mathrm{mi}$. north of Snake Rapids on the Churchill River (about 1.5 mi. northeast of the ne end of Sandy
Lake) at $55^{\circ} 46^{\prime} 44^{\prime \prime} \mathrm{N}, 106^{\circ} 33^{\prime} 30^{\prime \prime} \mathrm{W}$. He noted the occurrence here not only of pure yellow lilies but also intermediatecoloured ones with perianth parts either more orange-yellow and/or with some darker spots (pers. comm. D. Meyer to B. Irving, 19 Jan. 1984; pers. comm. to V.L. Harms, Feb. 1989).

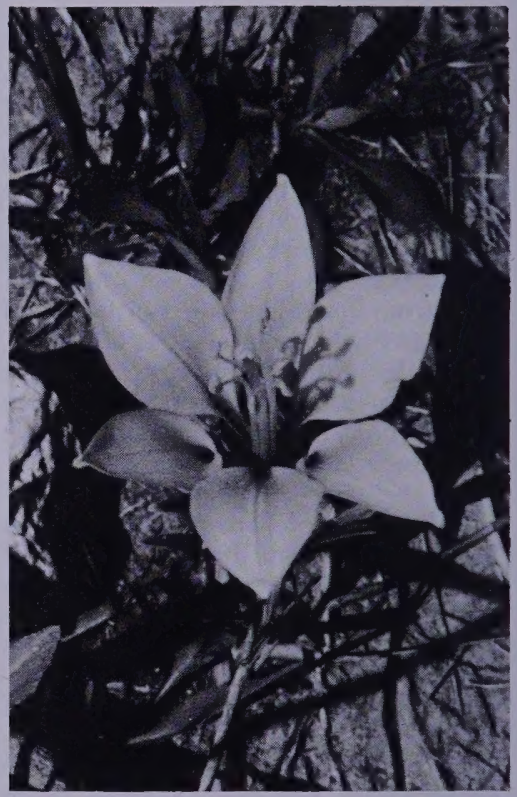

Yellow Immaculate Lily

Doris Silcox

The Yellow Immaculate Lily has also been found at several sites near The Pas, Manitoba, only 20-30 mi. east of the Saskatchewan border. Mr. R.A. Mitchell (pers. comm. R.A. Mitchell to B. Irving, 27 June 1983, and to V.L. Harms, 24 Feb. 1989 ) indicated that some years ago (date uncertain) he had discovered a yellow lily among a patch of normally-coloured red lilies beside Highway 287 about $4 \mathrm{mi}$. east of The Pas airport, about $12 \mathrm{mi}$. northeast of the town of The Pas, Man- 
itoba. His colour photograph shows a light yellow unspotted pure Yellow Immaculate Lily form of our native lily.

In June 1983 Mr. W.G. Mitchell discovered some yellow-flowered lilies growing among normal red lilies along Highway 10 about $6 \mathrm{mi}$. north of The Pas and several more just to the north of the first site, which he photographed. He also found some yellow lilies growing along Highway 287 about $1.3 \mathrm{mi}$. west of The Pas airport. His colour photograph of a yellow lily north of The Pas, however, shows flowers with the perianth parts bright yellow but with distinct dark red spots, thus being an apparently intermediate form. These yellow lilies were observed in subsequent years, the latest in 1987 (per. comm. W.G. Mitchell to B. Irving, 1983, and to V.L. Harms, Feb. 1989).

The yellow lily sites on his farm near Kelvington have been observed by Brian Irving since their discovery in 1982. His first site with a single pure yellow lily did not produce any more yellow lilies in subsequent years. The second site included three plants with pure yellow, unspotted perianth parts (although one of these was a deeper yellow), two plants with yellow perianth segments showing faint grayish spots and one plant with intermediate-coloured, orangish-yellow perianth parts with darker reddish spots, among numerous normally-coloured, reddish-orange-flowered native lilies. ${ }^{2}$ This second site continued to produce numerous lilies, including various yellow-flowered plants, from 1982 to 1986. In 1987, a severe spring frost resulted in a poor lily crop with no yellow-flowered plants observed. Again in 1988 there were very few lilies and no apparent yellow forms flowering, probably because of regional drought conditions. In 1988, however, a single plant of intermediate colour form showing yellowish-orange and somewhat spotted perianth parts was found about $1.5 \mathrm{mi}$. southwest of the latter site at the se corner of SE 21-3612-W2 (pers. comm. B. Irving to V.L. Harms, 5 Dec. 1988).
Brian Irving also indicated that in July 1986 he was with a Saskatchewan Natural History Society tour group that discovered a yellow lily of intermediate form on "Bainbridge Canyon Ridge" (in northeasternmost Pasquia Hills), almost $1 \mathrm{mi}$. south of the junction of highways 9 and 55 (about $2.5 \mathrm{mi}$. south of Mountain Cabin Resort and $58 \mathrm{mi}$. north of Hudson Bay), in SW 17-53-1-W2. His colour photograph of this plant shows a lily flower with yellow but spotted perianth parts (pers. comm. B. Irving to V.L. Harms, 5 Dec. 1988).

For a decade following its discovery in the Carlyle area, Doris Silcox has continued to observe and monitor the local natural lily population, including the Yellow Immaculate Lily plants in the roadside ditch across the road south of her home, as well as several lily transplants in her yard. The following 11-year "diary" illustrates the rather precarious existence of such colonies of conspicuous roadside wildflowers, where subjected not only to the vicissitudes of the weather, as has mainly affected the Kelvington population, but also to human disturbances and exploitation:

1978 - one yellow lily in patch of red-flowered lilies.

1979 - three yellow lily plants in patch of red-flowered lilies.

1980 - six yellow lily plants in patch with 129 red-flowered lilies. (One yellow lily plant on a steep clay bank which "washed out," exposing the bulb, was transplanted to yard).

1981 - five yellow lily plants among many red-flowered lilies.

1982 - many lilies initially appeared but the entire patch was cleaned out by the picking of thoughtless travellers.

1983 - fewer lilies appeared and again they were all picked by travellers.

1984 - only one deformed red-flowered lily and no yellow lilies occurred at the roadside ditch site.

1985 - no lilies appeared at the natural roadside ditch site although the three transplanted yellow lilies in the yard developed normally and bloomed.

1986 - again no lilies appeared at the road- 
side site, although the three transplanted lities developed normally and would have bloomed, but on 2 June a hailstorm devastated them.

1987 - the lily patch at the roadside site made a remarkable recovery with 43 redflowered lilies and 3 yellow lilies. One of the yellow lilies was collected as a voucher specimen for filing in the W.P. Fraser Herbarium, University of Saskatchewan (SASK), to document the distributional record.

1988 - no lilies bloomed at the natural ditch site, presumably because of extreme drought conditions; the three transplanted yellow lilies in yard bloomed well, with one plant bearing three flowers.

Despite their contribution to roadside beauty, it may be unfortunate that these showy wildflowers growing in a roadside ditch of a well-travelled thoroughfare near Carlyle are in such full view of thoughtless passers-by who may pick or dig them up, making quite doubtful their long-term survival here. Elsewhere in Saskatchewan and adjacent Manitoba, the survival of this native yellow lily form similarly appears rather precarious.

The presently known records of the Yellow Immaculate Lily in Saskatchewan and immediately adjacent regions of Manitoba and Alberta are mapped in Figure 1. The general localities appear surprisingly widely spaced, reflecting the highly sporadic occurrence of this yellow lily form within the overall range of the Western Red Wood Lily. Some local clustering is shown, however, by the two or more local colonies present near Carlyle, Kelvington and The Pas. As indicated in the figure and its legend, only the Carlyle area locality record has been documented by an actual voucher specimen as well as colour photographs, while most of the other locality records are substantiated by colour photographs and field verifications alone. The Parkside and Emerald Lake localities represent only sight records, but are based on the identifications of horticulturist A.J. Porter. The Carlyle area voucher specimen and colour photographs from the various other localities reported here are all filed in the W.P. Fraser Herbarium (SASK), University of Saskatchewan, Sas- katoon. Despite the lack of voucher specimens for most of the reported localities, they would appear to have been correctly identified as the Yellow Immaculate Lily. The only possible exception might be those of the Kelvington area of the first published Saskatchewan report, which were described by Brian Irving as more vigorous, larger $(5-10 \mathrm{~cm}$ taller), with their stems thicker, paler green and smoother textured than were the surrounding red-flowered Western Red Wood Lilies, differences not noted elsewhere as characteristic of the Yellow Immaculate Lily form. ${ }^{2}$ The colour photographs of the Kelvington yellow lily also seem to reveal perianth parts somewhat thicker and more lustrous-textured than typical for Lilium philadelphicum, but although widely spreading, these are not really reflexed. They were, however, verified in the field as the Yellow Immaculate Lily by Dr. J.R. Jowsey in 1982.

A colour form with yellow unspotted perianth parts has also been described and named within the Eastern Red Wood Lily, Lilium philadelphicum L. var. philadelphicum, as forma flaviflorum Williams. ${ }^{4}$ The latter, which has been recorded from as far west as Moosehorn, Manitoba, may not be genetically much different from our Yellow Immaculate Lily, perhaps even with the same determining genic alleles that occur instead in plants of the typical var. philade/phicum.

The genetic basis for the Yellow Immaculate Lily form is uncertain, but presumably it represents a recessive trait involving one or perhaps more genes. One or more intermediate expressions of perianth colour were often found at various sites including the following: (1) darker orange-yellow but unspotted, (2) pale yellow with faint grayish spots, (3) pale yellow with darker reddish spots and (4) orange-yellow with darker reddish spots.

The authors and the W.P. Fraser Herbarium, University of Saskatchewan, would be interested in details of other possible observations of Yellow Immaculate Lilies in natural habitats. 
Figure 1. The known distributional records of the Yellow Immaculate Lily in Saskatchewan and adjacent Alberta and Manitoba.

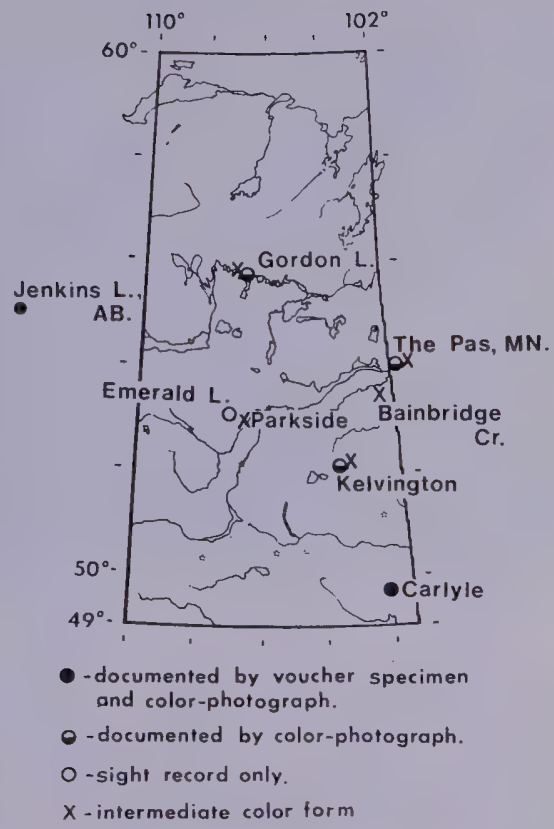

\section{ADDENDUM}

Recently, with our article already in press, we received a report from $\mathrm{Mr}$. Robert Barnhart that he had discovered about 20 yellow-flowered lilies, including various "half-breed" (i.e. intermediate) forms, among numerous typical red-flowered wild lilies, at four local sites about 4-5 mi. east-southeast and 8-9 mi. east-northeast of Saltcoats, Saskatchewan (specifically, NW 35 \& NW 26-23-1-W2 and NW 13 \& SE 24-24-33-W1 (pers. comm. R. Barnhart to V.L. Harms, 2 July 1989).

${ }^{1}$ BOIVIN, B. 1979. Flora of the prairie provinces. Part IV. Provancheria 5, Université Laval, Quebec (Reprinted from Phytologia 42-43).

2 IRVING, BRIAN. 1983. Color variation in Western Red Lily. Blue Jay 41:69-70.

${ }^{3}$ RAUP, H.M. 1934. Phytogeographical studies in the Peace and Upper Liard River regions, Canada, with a catalogue of the vascular plants. Contrib. Arnold Arboretum of Harvard University No. VI. 230 pp.

${ }^{4}$ SCOGGAN, H.J. 1978. Flora of Canada. Part 2. Nat. Mus. of Canada, Ottawa.

${ }^{5}$ VANCE, F.R., J.R. JOWSEY and J.S. MCLEAN. 1977. Wildflowers across the prairies. Western Producer Books, Saskatoon, Saskatchewan. 